\title{
ОБРАЗОВАњЕ НА ПУТУ СВИЛЕ
}

Од трговинских и економских веза дугорочније и трајније су образовне и везе културе. На Филолошком факултету Универзитета у Београду јапански језик изучава се од од 1976. године. Захваљујући нашим професорима и студентима добили смо уџбеник „Канђи“ који се не користи само у нашој земљи већ и на многим светским универзитетима, а има и српско, енглеско и руско издање. Већ три године одржава се „Balkan Japan Bowl“, a Филолошки факултет постао је регионални центар овог такмичења. О свим овим активностима РТС редовно извештава своју публику, доприносећи тиме афирмацији образовних вредности на Путу свиле.

Кључне речи: образовање, култура, Филолошки факултет, универзитет, јапански језик, уџбеник, РТС

\section{Улога медија}

"Медији немају слободу да стварају непостојеће друштвене вредности, иако могу утицати на начин на који ће се друштвене вредности исказивати." / Лоример, 1998: 312/1

Радиодифузна установа Радио-телевизија Србије има задатак да информише, образује и забави, али представља и институцију која има посебну улогу у друштвеном, културном и политичком животу Србије. Током шест деценија постојања РТС је израстао у значајну установу српске културе, сведочећи на специфичан начин о томе како су образовне и везе културе трајније од трговинских и економских веза. То потврђује и Архив РТС-а, највећи у региону. Ако би се емитовало само оно што је сачувано, наредних двадесет година не би моралао да се сними ни минут програма. На конкретним примерима

\footnotetext{
* natalja.sinanovic@rts.rs

1 Lorimer Rowland, MASS COMMUNICATION, A comparative introduction, Manchester University Press (Лоример Роланд, Масовне комуникације, Клио, 1998)
} 
показаћемо како РТС доприноси афирмацији образовних вредности на Путу свиле. ${ }^{2}$

Гледаоци РТС-а ових дана могу да гледају емисије различитих жанрова неколико јапанских дистрибутера. Сарадња је успостављена пре четири године, посредством Амбасаде Јапана у Србији, у сарадњи са Јапанском фондацијом. Тренутно се емисије гледају на РТС2 и РТС 3, а у плану је и емитовање путем интернета. Ту су на пример емисије“ Склад живота у Јапану“, „Традиционална јапанска култура“.

Серија „, Склад живота у Јапану“ уводи гледаоце РТС-а у свет јединствених јапанских обичаја који су и данас део животног стила Јапанаца заснованог на принципу "хармоније" с природом. Серија од пет двадесетоминутних емисија упознаје нас са пет важних свакодневних елемената који су изузетно важни за хармонију живота у Јапану: са простором, дрветом, папиром, цвећем и звуком.

\section{Образовање на Путу свиле}

За добар међународни положај факултета и универзитета важне су и међународне конференције. После Међународног конгреса слависта 2018. године, филолози су одржали још једну конференцију Међународну научну конференцију под називом "Првих 150 година модерног Јапана - Прве модернизације на Путу свиле”.

Конференција треба да допринесе истраживању културне, књижевне и научне историје Јапана на Путу свиле, у познавању са утицајима економског напретка, научних и културних идеја на јапански начин живота, науку, технолошки развој.

У периоду, после 250 година потпуне изолације, Јапан доживљава свој процват. Меиђи период почиње 1868. године и током тог периода Јапан, из феудалног друштва, постаје модерна држава. Процес модернизације у Јапану није био нимало лак, али је био врло ефикасан.

Оно што је врло важно када је модернизација Јапана у питању јесте и то да ова држава ниједан утицај са запада није прихватила у оригиналу, већ је све прилагођавала својој традицији. Тако је Јапан у процесу модернизације успео да задржи своју традицију и културу.

2 Рад „Образовање на путу свиле“ изложен на „3. Међународном симпозијуму о академским студијама Култура на путу свиле“, 2019 
У одржавање конференције укључило се неколико образовних институција Европе и Азије. Организатор конференције је Центар за студије Азије Филолошког факултета Универзитета у Београду, а суорганизатори су IAFOR, Међународни комитет слависта - Комисија за словенски свет и културе на путу свиле, Универзитет Осака, Универзитет Кобе, Хаџи Бекташ Вели Универзитет из Невшехира и Универзитет Васеда, што сведочи о високом признању наше јапанологије у свету.

Ове установе образовања окупиле су се и на III међународном симпозијуму о академским студијама Култура на Путу свиле, о чему смо такође извештавали.

Сусрет култура на Путу свиле (Синановић, Н. (5. мај 2019). Сусрет култура на путу свиле, $C a j \bar{u} P T C-a)$

\section{Најава:}

Професори из Европе, Азије и Америке окупили су се овог викенда на Међународном симпозијуму о академским студијама Култура на Путу свиле. О томе каква је била и каква је тренутно сарадња и који су даљи кораци у повезивању сарадње универзитета који се налазе на Путу свиле, разговарали су на Филолошком факултету Универзитета у Београду.

\section{Текст:}

Пут свиле није био само трговачки пут, већ и научна и уметничка линија која уводи источну филозофију, културу, образовање у Европу и обрнуто.

Зато би професори и истраживачи требало да истраже пут и одредишта на Путу свиле преко историје, културе, економије, политике, друштва, уметности и књижевности.

„Зашто је ово важно? Важно је да бисмо ми као Србија освестили свој идентитет, идентитет једне културе, а то смо ми на Путу свиле. И увек смо ту били. И у римско доба, и у средњем веку и у доба Немањића, и данас", рекла је проф. Љиљана Марковић, декан Филолошког факултета Универзитета у Београду.

Професор Киамицо Јуи са Универзитета у Кобеу истиче да су задовољни покренутом разменом. 
«Имамо споразум о званичној академској размени Универзитета у Београду и Универзитета Кобе, и на бази тог споразума радимо заједничка истраживања, размењујемо студенте", навео је Јуи.

Симпозијум који се одржава већ трећу годину, један је од највећих форума за студије Пута свиле, па су ту и представници Међународног академског форума, који окупља 70.000 професора.

«АЈФОР је међународна организација са седиштем у Јапану, основана 2009. године. Иницијатива Пут свиле као део АЈФОРА је нешто што радимо у сарадњи са Универзитетом у Београду. Веома смо срећни што је Универзитет у Београду пристао да буде домаћин форума за ову годину”, навео је проф. Џозеф Халдејн, председник Међународног академског форума.

Професор Хакан Јалап, председник Асоцијације за културе на Путу свиле објашњава да је симпозијум одлична прилика за професоре из Србије.

«Овде смо у Србији на трећем међународном симпозијуму академских студија. То је сјајна прилика не само за турске, већ и за српске професоре. Следећи пут ћемо можда бити у Турској, и моћи ћемо да покажемо српску историју, српско наслеђе из времена Пута свиле, и то целом свету", истакао је Јалап.

Скуп који је окупио стотину научника организовали су универзитети из Јапана, Русије, Турске, Србије и АЈФОР.

Иначе, Филолошки факултет је у саставу Универзитета у Београду, који је током септембра 2018. године бројним програмима обележио 210 година постојања.

Одржан је и трећи Џапан Бол. Такмичење које је добило регионални карактер, јер су дошли студенти пет универзитета у региону. На овогодишњем турниру учествовало је четрнаест тимова, а прва три места понели су студенти Универзитета у Београду, чиме су потврдили примат београдске школе јапанологије у региону. (Синановић, Н. 17. март 2019. Balkan japan Bowl, Cajū PTC-a)

Прво место освојила је екипа "Сенбонзакура", друго тим "Колико је сати” (оба тима чине студенти јапанологије Филолошког факултета), док је треће место припало тиму “Хиноиши” (састављен од студента Математичког факултета).

Такмичили су се и тимови из Загреба, Пуле, Бањалуке, Сарајева, Македоније. 
Тестирали су знање из историје, уметности и културе, поп-културе, језика и актуелних питања савременог Јапана.

Прочитано је и писмо принцезе Хисако Такамадо, која је покровитељ такмичења. Надметање, које је установљено у САД 1992. године има за циљ да мотивише академце да стекну нова знања и да унапреди вештине њихове комуникације.

Отправник послова Амбасаде Јапана у Србији, господин Цубота, рекао је да се радује што се на овакав начин проширује знање о Јапану, а да му је посебно драго што се такмичење одржава на Универзитету у Београду који има најдужу традицију учења јапанског језика у региону. Каже и то да се одкад је јапански премијер Шинзо Абе прошле године посетио Београд, примећује све бољи развој односа између Јапана и Србије, и Јапана и Балкана.

Професорка Љиљана Марковић, декан Филолошког факултета Универзитета у Београду, каже да су студенти показали боље знање него претходних година, а да је екипа сачињена од студената природних наука показала како се јапански језик може користити за научне матрице.

Подсећа да је овде настава јапанског отпочела 1976. године, а у овој, 2019., обележавамо 30 година од дипломирања првог студента јапанологије као потпуних четворогодишњих студија главне наставне групе.

На самом крају надметања, такмичари, као и гледаоци (такође студенти) попунили су анкету која ће, кажу организатори, својим сугестијама помоћи да такмичење наредне године буде још боље.

Овога марта јапански професори одржали су низ предавања. Припремајући чај, о томе да је чајна церемонија (која се учи и по десет година) истовремено и особен филозофски систем говорио је Хајаши Тошија из Јапанске фондације, Центара за јапанску културу у Будимпешти. Уследила је демонстрација икебане са освртом на историју и њене опште карактеристике господина Нишиуре Кихађира. Директор Националног института за јапански језик и лингвистику проф. Прадеши Прашанта, говорио је о "Онлајн ресурсима за истраживање јапанског речника". За разлику од ових предавања која су била на јапанском језику, уз симултан превод на српски, професор Мићитака Сузуки предавање је одржао на српаком језику. Некада професор на 
Универзитету Окајама, а сада професор Тохоку Гакуин Универзитета говорио је о "Идолима у јапанској култури". Професор Сузуки предаје историју уметности и српски језик. Његова посвећеност српској култури и језику траје више од четири деценије. На Хиландару је прихватио православље, а монаси су му дали име Сава. Каже да универзитет на коме сада предаје тренутно нама уговор са Универзитетом у Београду, и да је осим предавања његов циљ овогодишњег боравка у Београду и успостављење институционалне сарадње.

И на крају треба подсетити да смо захваљујући нашим јапанолозима добили и први уџбеник јапанског језика и писма „Канђи“ производ је активне интеракције наставника и студената јапанског језика. Доживео је четири издања, а данас се користи у више од 50 универзитета у свету. Употребом савремених метода и технологија после издања на српском појавила су се издања и на руском и енглеском језику. Тако су наши професори на руском издању сарађивали са колегама које раде на универзитетима Ломоносов у Москви, Тјумену и Вороњежу, као и са колегама са Универзитета у Кобеу, где су објавили издање на енглеском језику за наставу јапанског језика страним студентима. То показује да је наш програм за јапанологију интернационализован у правом смислу те речи.

\section{ЛИТЕРАТУРА:}

Брикс А. и П. Колби (2005). Увод у студију медија, Београд: Клио.

Лексикон образовних термина. (2015). Београд: Учитељски факултет.

Л. Роланд (1998). Масовне комуникације. Београд: Клио.

М. Аљоша и М. Богдановић (2007). Социолошки речник. Београд: Завод за уџбенике.

П. Џејмс (2011). Медијска писменост. Београд: Клио.

\section{Остала литература:}

Извештаји са Сајт-а РТС-а

Синановић Н. (2019). Сусрет култура на Путу свиле. РТС. Доступно преко http://www.rts.rs/page/stories/ci/story/8/kultura/3510974/susret-kulturana-putu-svile.html (30.07.2019.) 
Синановић Н. (2019). Такмичење „Balkan Japan Bowl“. РТC. Досптупно преко http://www.rts.rs/page/stories/ci/story/124/drustvo/3456502/srpskistudenti-najbolji-u-poznavanju-japanskog-jezika.html (30.7.2019.)

"lkan Japan Bowl»

Склад живота у Јапану. РТС. Доступно преко http://www.rts.rs/page/tv/sr/ story/255/rts-3/3144690/svakodnevni-sklad-zivota-u-japanu-prostor-1-5. html (30.7.2019.)

Традиционална јапанска култура. PTC. Доступно преко http://www.rts. rs/page/tv/sr/story/255/rts-3/3454033/tradicionalna-japanska-kulturajapanski-muzicki-instrumenti-716.html (30.7.2019.)

\section{Natalija Sinanović}

\section{EDUCATION ON THE SILK ROAD}

\section{Summary}

Educational and cultural links are more durable than trade and economic ones. At the Faculty of Philology in Belgrade within the University of Belgrade the Japanese language has been studied since 1976. Thanks to our professors and students we got a textbook "Kanđi" which is being used not only in Serbia, but also at many world universities. It has Serbian, English and Russian editions. "The Balkan Japan Bowl" contest has been going on for three years now and the Faculty of Philology has become the regional center for this contest. The RTS is informing its viewers about all these activites on a regular basis, in that way contributing to affirmation of educational values on the Silk road.

Key words: education, culture, Faculty of Philology, university, Japanese, texbook, RTS 